\title{
Individualismus versus holismus: Nástin pokusu o řešení teoretického dilematu
}

\author{
Individualism vs. Holism: An Outline to Attempt a Solution \\ to the Theoretical Dilemma
}

Jiř́ Šubrt

\begin{abstract}
This article deals with one of the theoretical dilemmas of contemporary sociology: the dualism of the individualistic and holistic approaches. One of the most famous attempts to overcome this dualism is the structuration theory of Anthony Giddens, and alongside it we find the conception of social realism of Roy Bhaskar and Margaret Archer. Their efforts to link individualistic and holistic approaches are based on a vari-focal attempt to explain the theoretical issues from both perspectives - individualistic and holistic. The author of this article believes that this problem can be solved alternately where both perspectives are 'blended' in a theoretical explanation demonstrating that the concepts which we use in sociological theory - actor, action and structure - are inherently of dualistic nature, ie. they are 'duplex'.
\end{abstract}

KEY WORDS sociological theory, individualism, holism, homo duplex, dualism.

Dnešní situace v oblasti sociologické teorie je hodně komplikovaná a dosti nepřehledná. Je to dáno do značné míry tím, že teoretické myšlení v sociologii od jejích počátků formují názory, které jsou založeny na mnohdy diametrálně odlišných východiscích. Důsledkem toho je, že se v jeho rámci opakovaně reprodukují určitá teoretická dilemata, na která narážejí i všechny dnešní pokusy $\mathrm{v}$ oblasti sociologické teorie. Na jedno $\mathrm{z}$ těchto dilemat se chceme zaměřit v následujícím textu.

\section{Individualismus, holismus a další teoretické dichotomie}

Teoretické dilema, kterým se chceme $\mathrm{v}$ této stati zabývat, bývá v literatuře spojováno s různým terminologickým označením. Brian Fay v knize Contemporary Philosophy of Social Science klade do kontrapozice pojmovou dvojici atomismus a holismus. Podle atomismu představuje každý jedinec svébytnou jednotku sociálního života nadanou schopností „ř́dit své jednání na základě svého přesvědčení a tužeb“ (Fay 2002: 45). Atomisté chápou společnost jako souhrn jednotlivců a zároveň soudí, že sociální celky jsou převoditelné na činnost jednotlivců, kteří je tvoří. Fay spojuje atomismus s přesvědčením o „fundamentální singularitě jednotlivců“, o kterých se uvažuje, ,jako by tím, čím jsou, byli nezávisle

Sociálni studia. Katedra sociologie FSS MU, 1/2012. S. 29-44. ISSN 1214-813X. 
na svých vztazích k jiným lidem“ (tamtéž: 46). Za filozofického zakladatele atomismu považuje Thomase Hobbese, v sociálních vědách 20. století tuto pozici výrazně reprezentuje Friedrich von Hayek. ${ }^{1}$

Protikladem atomismu je holismus, který Fay charakterizuje jako doktrínu, ,podle které jsou vlastnosti jedinců výhradně funkcí jejich místa ve společnosti nebo v nějakém širokém systému významů“ (Fay: 67). Podle holismu je nutné brát za základ sociálních teorií vždy sociální celky, nikoli jejich jednotlivé př́slušníky. Holismus nepřipouští, že by bylo možné teorie týkající se sociálních celků redukovat nebo převádět na teorie o jednotlivcích. Pro sociální vědy je klíčovou osobností holismu Émile Durkheim, za modernější verzi holismu považuje Fay především strukturalismus (Lévi-Strauss, Foucault aj.).

Protiklad, který Fay popisuje, má řadu aspekti̊, jež je možné vyjádřit v podobě dalších dualismů. O třech z nich hovoří ve své knize Understanding Social Theory Derek Layder (1994: 3). Je to dualismus individuum-společnost, mikro-makro a jednání-struktura. Distinkce individuální-sociální, kterou autor považuje za nejstarší a zároveň i nejvytrvalejší dilema sociologického myšlení, v zásadě koresponduje s opozicí atomismus-holismus, o které hovoří Fay. Layder upozorňuje, že problém tohoto dualismu spočívá v tom, že jednotlivce nelze stavět do prŕkré opozice vůči společnosti jednoduše proto, že mnoho potřeb a motivací, které lidské jedince ovlivňují, je vytvářeno sociálním prostředím společnosti, ve které tito lidé žijí. Jinak řečeno, neexistuje společnost bez individuí, kteří ji utvářejí, a zároveň nejsou jedinci, kteří by mohli existovat mimo vliv společnosti (Layder 1994: 3).

Layderův výčet tří dualismů je nutné doplnit ještě o jeden, který sahá svým původem hluboko do minulosti, nebot' má kořeny ve stř̌edověké scholastické filozofii. Jedná se o opozici nominalismus a realismus. V aplikaci na sociologické myšlení vyjadřuje pojem realismus předpoklad, že entity, které jsou označovány souhrnnými pojmy, jako jsou např́íklad sociální třída, organizace, společnost nebo veřejné mínění, reálně existují. Nominalismus má naopak takové pojmy za pouhá jména, která označují určité intelektuální konstrukce, nikoli však něco, co by mělo svou samostatnou reálnou existenci. Reálně totiž podle nominalistů existují pouze konkrétní jedinci a jejich individuální jednání. Nominalistická pozice je v dějinách sociologického myšlení tradičně spojována s Weberem, realistická s Durkheimem.

James Coleman (1986), který se zabývá problematikou vzájemného vztahu mezi sociální mikro- a makroúrovní (micro-/macro-level), konstatuje, že značná část sociální teorie a sociálního výzkumu - a týká se to především Durkheima a jeho následovníků - se zakládá výlučně na zkoumání vztahů na makrosociální úrovni. Autor tento př́stup označuje jako metodologický holismus (methodological holism) a klade jej do zásadního protikladu k metodologickému individualismu (methodological individualism), jenž je zakotven v teorii jednání. ${ }^{2} \mathrm{O}$ sociologické teorii uvažuje Coleman ze dvou hledisek: první se týká předmětu

$1 \quad$ Fay uvádí jako př́klad atomistického stanoviska citát z Hayekovy práce Individualism and Economic Order (1949), v němž se praví: „Sociálním jevům nelze porozumět jinak než skrze porozumění individuálním činům zaměřeným na jiné lidi a řídícím se jejich očekávaným chováním“ (Fay 2002: 46).

2 Dodejme, že pojem metodologický individualismus odpovídá v zásadě stanovisku, které Fay označuje výrazem atomismus; metodologický holismus koresponduje s Fayovou charakteristikou holismu. 
výkladu, druhý metody výkladu. Z hlediska předmětu spatřuje Coleman hlavní úkol sociologie ve výkladu sociálních fenoménů, nikoliv ve výkladu způsobů chování jednotlivých osob. Avšak vzhledem k metodě zaujímá tento autor jinou perspektivu: jako stoupenec metodologického individualismu, usilujícího o vysvětlení chování sociálních systémů na základě analýzy individuálního jednání (Coleman 1994: 2 a dále), soudí, že vysvětlení na úrovni individuálního jednání je „fundamentálnějšsi'“ a umožňuje hlubší „pochopení“ než vysvětlení zůstávající v rovině systému.

Problematice vztahu mikro- a makrosociologie věnuje dlouhodobě pozornost Randall Collins. Mikrosociologii charakterizuje jako detailní analýzu toho, „co si lidé v průběhu svého bezprostředního prožívání myslí, co říkají a dělají“. Makrosociologii naproti tomu chápe jako oblast sociologie, která se zabývá „rozsáhlými a dlouhodobými sociálními procesy“; tyto procesy bývají často chápány jako jakési „sebezáchovné entity“, jedná se např́íklad o „stát“, „organizace“, „vrstvy“, „hospodářství", „kulturu“ nebo „,společnost“ (Collins 1981: 984). Ve své knize Theoretical Sociology (1988) Collins rozlišuje makroteorie, mikroteorie a mezoteorie. $\mathrm{K}$ makroteoriím řadí evolucionismus, systémovou teorii, politickou ekonomii (marxismus), teorii konfliktu, sociální změny a stratifikace. K mikroteoriím přiřazuje koncepce lidského Já (Self), interakcionismus, sociální konstruktivismus, strukturalismus, sociolingvistiku a teorie sociální směny. Jako mezoteorie označuje teorii strukturace (Giddens), teorii komunikativního jednání (Habermas), teorii sítí a teorie organizace. ${ }^{3}$ Ve své vlastní teoretické koncepci orientované na rozpracování mikrosociologické perspektivy Collins naznačuje, že vyostřené pojetí dualismu mikro a makrostruktury je de facto zavádějící, nebot' makrostruktury lze z mikrosociologické perspektivy nahlížet jako agregáty mikrosituací; jinak řečeno: makrofenomény lze transponovat do podoby spojených „mikroudálostí“ (Collins 1981: 987-990).

Problémy týkající se vztahů mezi mikro- a makro-rovinou a mezi subjektivním a objektivním bývají v soudobé sociologické teorii často spojovány ještě s jedním dualismem, a to dualismem jednání a struktury. Uvedené pojmy představují pro mnohé soudobé sociální teoretiky jakýsi konceptuální základ, na kterém má být sociální teorie budována. Jednání a struktura bývají často charakterizovány jako „subjektivní“ a „objektivní“ stránka sociální reality. Subjektivní stránka je spojována s jedinci, jejich subjektivními kvalitami a individuálním jednáním; objektivní stránka je spojována s existencí sociálních struktur, které mají objektivní charakter a jsou na individuální vůli a jednání jednotlivých aktérů relativně nezávislé. Anthony King k tomu dodává: ,jednání se vztahuje k činnosti [...], obvykle označuje

$\mathrm{Na}$ otázku, která témata či teorie mají být přiřazovány $\mathrm{k}$ jednotlivým úrovním sociologického bádání neexistuje jednotný názor. Dokládá to i nejnovější pokus klasifikovat teorie na mikro-, mezo- a makroúrovni, který přináší kniha Contemporary Sociological Theory: An Integrated Multi-Level Approach, jejímž autorem je Doyle Paul Johnson (2008). Johnsonova klasifikace se $\mathrm{v}$ řadě ohledů liší od Collinsova prístupu. S mikroúrovní spojuje tento autor problémy symbolického interakcionismu, fenomenologie, sociální směny a racionální volby; s mezoúrovní teorie komunit, organizací, trhu a socioekonomických tříd; s makroúrovní teorie sociálního rádu, strukturního funkcionalismu, neofunkcionalismu, konfliktu a kritickou teorii. Navíc Johnson ještě hovoří o mnohaúrovňových př́stupech, ke kterým řadí feministickou teorii, teorii strukturace, sociobiologii, kulturní sociologii (cultural sociology) a postmodernismus. 
konání jedinců nebo skupin jedinců.“ Struktura naproti tomu „označuje pravidelné, relativně pevné, objektivní a zobecnělé rysy sociálního života“; pojem se obvykle „,vztahuje k sociálním institucím nebo ,systémům‘, ,silám“ či ,proudům““ (King 2006: 291). Patrně nejznámějším pokusem, jak překonat dualismus jednání a struktury, a zároveň překonat i další dilemata, o kterých jsme se zmínili, je Giddensova teorie strukturace a paralelně vedle ní formulovaná a jí př́ibuzná koncepce sociálního realismu Roye Bhaskara a Margaret Archerové.

Anthony Giddens podobně jako před ním i Parsons usiluje o položení teoretických základů sociálních věd. Parsonsův pokus založený na spojení „voluntaristické“ teorie jednání (reprezentující individuální svobodu) a strukturně-funkcionalistické teorie (reprezentující sociální řád) nepovažuje Giddens za zdařilý. Naopak soudí, že v něm zůstává nepřekonaná propast mezi jednáním a strukturou. Giddensovo teoretické myšlení je založené na kritice Parsonse. Giddens kritizuje Parsonsův funkcionalismus jako překonaný, ${ }^{4}$ ale zároveň připouští, že na problémy, které do sociologie přinesli funkcionalisté, nelze jednoduše zapomenout. Giddens se domnívá, že pojem funkce v sociologii použitelný není. Připouští ale, že mnozí, kteří kritizovali funkcionalismus, upadali do subjektivismu; jako např́íklad fenomenologie. V oblasti analýzy institucí a široké škály sociálních procesů je podle Giddense funkcionalismus silnější než fenomenologická sociologie. Dospívá proto k závěru, že chceme-li odstoupit od funkcionalismu, musíme jít na problém poněkud jinak než fenomenologická sociologie.

Giddens se snaží překonat funkcionalismus prostřednictvím teorie strukturace. Ta $\mathrm{v}$ jeho díle postupně krystalizovala v průběhu 70. a první poloviny 80. let 20. století. Je formulována zejména v knihách New Rules of Sociological Method (1976) a Central Problems in

Giddens definuje funkcionalismus jako typ doktríny, která soudí, že „společnost nebo sociální systém má potřeby“. Této doktríně Giddens oponuje z několika důvodů:

1. Díky zdůrazňování systémových potřeb nejsou funkcionalističtí autoři schopni vidět lidské bytosti jako rozumně uvažující aktéry, kteří jsou si z velké části vědomi toho, co dělají.

2. Systém nemá potřeby, potřeby mají lidé. Sociální systém nelze na základě funkcionalistického př́stupu dostatečně popsat a vysvětlit (Giddens 1981: 90).

Giddensova námitka se týká toho, že ve funkcionalistické teorii není adekvátně pochopeno lidské jednání ve smyslu, který musí zaujmout tento termín v rekonstruované sociální teorii (Giddens 1981: 91).

I když se pojem jednání objevuje (zejména pod vlivem M. Webera) i v Parsonsově koncepci, Giddens nepovažuje tento strukturálně-funkcionalistický koncept jednání za dostatečný a adekvátní. Parsonsovi vytýká, že v jeho teorii není postižena úloha lidských aktérů jako bytostí, které svým jednáním produkují a reprodukují sociální instituce, a tím i celý sociální systém.

Giddens v tomto smyslu vyzvedá proti Parsonsovi Ervinga Goffmana, u něhož nalézá koncept jednajících lidských bytostí jako kvalifikovaných a znalých agentů, kteří využívají - s určitou rutinou - své vědění $\mathrm{k}$ produkci a reprodukci sociálních vazeb. To je podle Giddense koncept, který má v sociální teorii ústřední význam.

Poslední Giddensovou námitkou proti funkcionalismu je, že sociální systém nemá potřeby, a dokonce nemá ani funkcionální nezbytnosti (Giddens 1981: 92). Většina funkcionalistů považuje potřeby nebo požadavky za atributy sociálního systému a věří, že představují klíčovou roli v pochopení tohoto systému. Proti tomu Giddens namítá, že sociální systémy nemají potřeby, přinejmenším ne ve smyslu, v jakém je mají individuální aktéři. 
Social Theory (1979). Myšlenky obsažené v těchto knihách Giddens následně rozvinul v díle The Constitution of Society (1984). Výstavba a intence této třetí knihy je někdy prrirovnávána k Habermasově Theorie des kommunikativen Handelns (1981). Podobně jako Habermasovi jde i Giddensovi o reformulaci sociální teorie a o překonání jistých omezujících tradic. Proklamovaným cílem této koncepce je propojení jednání a struktury, a zároveň i překonání vzájemného rozporu mezi mikroteorií a makroteorií. Klíčovými pojmy se pro něj stávají jednání a struktura, základní otázkou to, jak tyto pojmy k sobě navzájem co nejvíc přiblížit.

Tradiční sociologický dualismus představovaný pojmy jednání a struktura má být podle Giddense nahrazen principem duality. Struktura není protikladem k jednání, nýbrž je to druhá dimenze téže věci. Na jednání a strukturu nelze pohlížet jako na samostatné problémy, nýbrž jako na vzájemný vztah. Společenské struktury jako takové nestojí proti jednání individuálních aktérů, nýbrž do tohoto jednání bezprostředně vstupují; a naopak, jednání aktérů vytvářjí struktury. Giddens to nazývá dualitou jednání a struktury, nebo také jen dualitou struktury. Dualismus individua a společnosti je v jeho teorii nahrazen dualitou jednání a struktury (Giddens 1988: 215), respektive dualitou struktury. ${ }^{5}$

Teorém duality struktury ř́ká, že struktury sociálního systému jsou jak médiem, tak zároveň i výsledkem sociálního jednání (Giddens 1981: 92, Giddens 1988: 77). Pojmy struktura a jednání označují analyticky rozdílné momenty skutečnosti strukturovaných systémů jednání. Struktury samy neexistují vůbec jako samostatné fenomény prostorové a časové povahy, nýbrž pouze ve formě jednání a praktik lidských jedinců. Struktura se stává reálnou pouze v konkrétních realizacích praktického strukturování sociálních systémů (Giddens 1988: 290). Aktéři zahrnují struktury do svého jednání a struktury propůjčují tomuto jednání určitou jistotu a kontinuitu. Struktura na jedné straně omezuje jednání, ale na druhé straně ho také umožňuje. Bez struktur bychom byli neustále dezorientovaní, a tudíž bezradní při zvládání našeho všedního života. Na druhé straně vytyčují struktury našemu jednání hranice. Př́kladem toho, co je prredpokladem i prostředkem, a zároveň také výsledkem sociálního jednání, je podle Giddense lidská řeč: Jednotlivé řečové akty mohou vznikat pouze v rámci abstraktního souboru pravidel řeči, zároveň však tyto řečové akty stále znovu reprodukují řeč jako abstraktní soubor pravidel. Vyslovím-li větu, je to určitý projev mého jednání, který zároveň jako nezáměrný důsledek udržuje při životě (reprodukuje) systém řeči (Müller 1992: 175).

Podobným směrem jako Giddensova teorie strukturace mírí také realistická ${ }^{\text {teo- }}$ rie reprezentovaná Royem Bhaskarem a Margaretou Archerovou. Bhaskar charakterizuje svou koncepci jako „transformační model sociálního jednání“ a konstatuje, že je slučitelná

$5 \quad$ Podle M. Archerové existují čtyři virulentní dualismy (Archer 1982: 456), které se táhnou teoretickou diskusí a se kterými se Giddens snaží vypořádat: dualismus mezi subjektem a objektem, mezi vysvětlováním a chápáním, mezi voluntarismem a determinismem, mezi statikou a dynamikou. Giddensova strategie spočívá v tom, že tyto dualismy převádí na duality.

6 Realistická teorie tvrdí, že součástí společenské skutečnosti jsou jevy, struktury a instituce, které nelze jednoduše převést a redukovat na lidské jedince, jejich vědomí a individuální jednání. Tyto nadindividuální entity nelze vykládat nominalistickým způsobem, nýbrž je nutné je vysvětlovat z realistických pozic, nebot' existují reálně. 
s koncepcí Giddensovou. ${ }^{7}$ Podle Bhaskarova transformačního modelu se společnost „skládá ze struktury a jednání. Struktura předchází individuální jednání, ale může být reprodukována a transformována prostřednictvím individuálního jednání. Jedinci jsou konfrontováni se sociální strukturou, která je sice omezuje, ale v konečném důsledku je neurčuje. Svým jednáním mohou jedinci se strukturou manipulovat, mohou reinterpretovat svou situaci a vytvořit tak nové formy jednání. Tímto způsobem jsou jedinci schopni sociální strukturu pozměňovat" (King 2006: 306).

Margaret Archerová v návaznosti na Bhaskara rozvíjí to, co označuje jako ,morfogenetický př́stup“ (Archer 1995). ${ }^{8}$ Ten je založen na dvou základních předpokladech: 1. „struktura nutně předchází jednání (činům), jež ji proměňuje (proměňují)“, 2. „rozvoj struktury nutně následuje až po jednání“ (Archer 2008: 9); jinak řečeno: výkon jednání je závislý na struktuře, a zároveň platí obráceně i to, že struktura je závislá na jednání.

Giddensova snaha o propojení individualistického a holistického př́istupu je založena na tom, že během teoretického výkladu střídavě mění svoje stanoviště a teoretické otázky se snaží vysvětlovat tak, že se na ně stř́idavě dívají z obou pozic - individualistické i holistické. Autor jakoby ř́kal: $v$ prvém kroku je nutné zaujmout individualistickou pozici, nebot' jsou to jedinci, kteří svým jednáním vytvářejí struktury; v druhém kroku je ale třeba přijmout holistickou perspektivu, protože tyto již utvořené struktury ovlivňují následná individuální jednání. Ve třetím kroku se vracíme $\mathrm{k}$ individualistickému úhlu pohledu, a to proto, že individua jsou, jak Giddens konstatuje, schopna svým jednáním existující struktury nejen reprodukovat, ale i modifikovat a přetvářet. S podobným typem výkladu se setkáváme i v rámci sociálního realismu u Roye Bhaskara a Margaret Archerové. I zde je využita postupná alternace obou protikladných pozic, avšak oproti Giddensovi, jenž považuje za výchozí moment výkladu individuální jednání, zde je za tento bod označena objektivní existence struktur.

Giddens, Bhaskar i Archerová volí v otázce řešení vztahu jednání a struktury strategii co nejtěsnějšího přiblížení obou těchto momentů, avšak úspěšnost tohoto úsilí byla v řadě diskusí zproblematizována a zpochybněna. To je důvod, proč má cenu uvažovat o alternativě.

7 Bhaskar rozlišuje čtyři modelová řešení vztahu individua a společnosti. V prvním výkladovém modelu, který je připisován Weberovi, je to individuum a jeho (voluntaristické) jednání, co vytváří společnost. V druhém modelu, který lze přisoudit Durkheimovi, je to naopak společnost, která determinuje jednotlivce a jeho jednání. Bhaskarovi nevyhovují uvedené dva modely stejně, jako mu nevyhovuje ani třetí - dialektický - model, jenž lze ilustrovat př́stupem Bergera a Luckmanna. Ti se snaží problém řešit tak, že postulují stř̌́davý konstitutivní vliv jedince na společnost a společnosti na jedince (jednotlivci utvářejí společnost, a ta zase formuje je ve vzájemném dialektickém procesu). Proti těmto třem modelům staví Bhaskar svou - čtvrtou - variantu, kterou označuje jako the transformational model of social activity. V něm se předpokládá, že společnosti mají logickou a časovou prioritu před každým jednotlivcem, a proto je nesprávné ř́kat, že lidé „,ělaji““ společnost; adekvátnější je konstatovat, že lidé reprodukují nebo transformují předem dané formy a praktiky. Společnost nemůže existovat nezávisle na vědomém lidském jednání, ale nedá se říci, že by byla jednoduše výtvorem lidí (Bhaskar 1978: 10-13).

8 Morfogenetický prrístup zdůrazňuje, že opakované sociální jednání vede k vytváření určitých vzorců nebo tvarů (Archer 1995: 5). Orientuje se na zkoumání otázky, jakým způsobem aktéři reprodukují (morfostáze) nebo proměňují (morfogeneze) sociální struktury a jsou v tomto procesu sami ovlivňováni a formováni (Archer 2008: 9). 
Problém, o který se zde jedná, nelze podle našeho názoru úspěšně řešit ani postupným střídáním individualistické a holistické perspektivy, ani snahou o co největší vzájemné přiblížení jednání a struktury. K řešení, které navrhujeme, jsme byli do jisté míry inspirováni Émile Durkheimem a jeho konceptem ,homo duplex“ (Durkheim 1913, 1914 [1995]). Strategii, kterou volíme, je nikoli převedení dualismu jednání a struktury na dualitu, jako je tomu u Giddense, nýbrž př́stup, v němž jsou všechny základní pojmy - aktér, jednání i struktura - uchopeny perspektivou, která je naznačena ve zmíněném Durkheimově konceptu. Jinak řečeno, domnívám se, že je zapotřebí, aby se obě perspektivy vzájemně nikoli co nejvíce přiblížily, nýbrž, aby se tak říkajíc ,prolnuly“ v teoretickém výkladu, který bude ukazovat, že pojmy, s nimiž v sociologické teorii pracujeme - aktér, jednání a struktura - mají ze své podstaty dualistickou povahu, tedy že jsou „duplexní“.

\section{Homo duplex}

Émile Durkheim konstatuje, že lidská bytost je bytost rozdvojená, a to dokonce vnitřně protikladným způsobem. Na různých místech svého díla Durkheim charakterizuje toto rozdvojení různým způsobem, avšak smysl této charakteristiky zůstává zachován. Durkheim se odvolává na tradiční dualismus, který proti sobě stavěl tělo a duši. Sám hovoří o „konstituční dualitě lidské přirozenosti““ (Durkheim 1995: 17), o rozdvojení člověka na bytost fyzickou a bytost sociální. Říká, že v každém z nás existují dvě vědomí, dva aspekty našeho psychického života: osobní a neosobní. Naše fyzické tělo - na jedné straně - je zdrojem našich neutuchajících prání a tužeb, našeho egoismu. Naše socializovaná bytost - na straně druhé - je výtvorem společnosti, která žije a jedná skrze nás a kontroluje a brzdí projevy našeho egoismu prostřednictvím internalizovaných morálních zásad.

Dodejme, že k podobnému závěru dospěli i mnozí další myslitelé před Durkheimem i po něm. Tradici dualistického myšlení ve filozofii můžeme sledovat od antiky přes Descarta až do současnosti. Na rozdvojenost lidské přirozenosti upozornil Auguste Comte, který hovořil o opozici mezi egoismem a altruismem. Egosimus podle Comta lidské jednání inspiruje a dodává mu energii, altruismus ho usměrňuje a ukázňuje společensky žádoucím směrem (Keller 2004: 75). Podle Georga Simmela je člověk dvojakou bytostí s výrazně ambivalentní povahou (Mahlmann 1983). V eseji „Brücke und Tür“ (Most a dveře) charakterizuje situaci lidské bytosti, jejíž jedna část směřuje vně sebe, je orientována navenek, je přitahována společností, asociací s druhými lidmi; zatímco druhá část této bytosti je světem sama pro sebe, která touží po autonomii, nezávislosti a odstupu od druhých osob (Simmel 1957: 1-7). George Herbert Mead (1977: 209-246) podává charakteristiku lidského ,já“ - „Self“ - jako rozporuplné jednoty dvou složek, „I“ a „Me“. „I“ je individuální, subjektivní složkou, která je aktivní a tvořivá. „Me“ je objektivní, pasivní složkou, která je utvářena především zvnitřněnými postoji sociální skupiny či společnosti, k níž jednotlivec náleží.

Durkheim si klade otázku po prríčině dualismu lidské přirozenosti a dospívá k závěru, že tato antinomie „odpovídá v podstatě dvojí existenci, kterou souběžně vedeme“. Jedna část naší existence je čistě individuální a má kořeny v naší tělesnosti. Druhá část naší existence je sociální a my v ní představujeme „,pouze prodloužení společnosti“ (Durkheim 1995: 30). Společnost má přitom, podle autora, svou „vlastní podstatu a tím i požadavky zcela odlišné 
od těch, které jsou zahrnuty v naší individuální přirozenosti. Zájmy celku nejsou nutně shodné se zájmy jeho částí. Proto se společnost nemůže utvářet ani udržovat, aniž by od nás nevyžadovala věčné oběti, které jsou pro nás těžké. Jedině tím, že nás převyšuje, nás nutí, abychom překonávali sami sebe. A překonávat sebe sama znamená pro každou bytost vysvléknout se do jisté míry ze své podstaty, což není možné bez většího či menšího napětí“ (tamtéž: 31 ).

Durkheim integroval ve svém pohledu na člověka dvě perspektivy, které jsou obvykle uplatňovány odděleně. Perspektiva, v niž je jedinec nahlížen jako jedinečná bytost nadaná vlastním ,egem“, individuálními dispozicemi a vůlí, je uplatňována spíše v některých humanitních disciplínách a ve filozofii. Perspektiva, v níž je nahlížen jako socializovaná bytost, je vlastní sociologickému myšlení. Ostatně i Durkheim sám a celé jeho dílo jsou toho dokladem. Autor sice hovoří o dvou složkách lidské přirozenosti, avšak ve své sociologické koncepci tu první zcela programově ignoruje a do svých teoretických a metodologických úvah ji téměř nezahrnuje. Od Durkheimových dob vyvinula obecná sociologie celou řadou pojmů, v nichž je schopna zachytit společenské kvality jednotlivců, ale k teoretickému uchopení jejich individuálních stránek terminologicky disponovaná není. Hovoř́me-li v sociologii o jedinci, používáme nejčastěji takové výrazy jako status, role či habitus, ${ }^{9}$ a to všechno jsou pojmy, které označují pouze tu druhou - společenskou či socializovanou - stránku lidské bytosti.

Snažíme-li se na tomto místě na Durkheima určitým způsobem navázat a nechat se jeho koncepcí „homo duplex“ inspirovat, znamená to, že chceme vyzvednout a aktualizovat i to, co sám Durkheim ve své teorii odsunul stranou - a to je důsledné promítnutí dualistického pohledu na člověka do pojetí aktéra i do všech dalších klíčových konceptů sociologické teorie. Durkheim se do značné míry vyjadřuje $\mathrm{v}$ pojmech a představách, které $\mathrm{v}$ té či oné míře zastaraly a mohou dnes působit jako anachronismus. Nejde nám na tomto místě o to, abychom se snažili všechna dílčí tvrzení tohoto autora obhájit, nýbrž abychom se pokusili využít to nejdůležitější, co si podle našeho názoru podrželo svoji platnost a aktuálnost do dnešních dnů, a to je právě ona vůdčí idea vnitřní dvojakosti „homo duplex“. Tuto ideu chceme převzít a pokusit se ji rozvinout, ovšem nikoli striktně v tom pojetí a kontextu, se kterými pracuje francouzský sociolog. Budeme ji chápat spíše jako jakousi volnou inspiraci, jíž se necháme ovlivňovat i při zkoumání těch otázek, jimiž se Durkheim nezabýval. ${ }^{10}$ Domníváme se, že pokud tuto ideu přijmeme, můžeme od ní dále konsekventně odvíjet úvahy o povaze jednání, interakcí a struktur, které lze všechny rovněž nahlížet perspektivou „duplex“.

V individualistických koncepcích bývá jednání obvykle chápáno jako jednosměrný akt, který vychází od jedince a ve většině případů je orientován směrem ven tak, aby zapůsobil na něco nebo na někoho v okolním světě. $Z$ dialektické perspektivy je ale celá záležitost komplikovanější, protože už v samotném tomto jednotlivém aktu se od samého začátku ohlašuje

9 Připomeňme, že pojem „habitus“ zpopularizoval Pierre Bourdieu, u kterého nalézáme také ještě př́buzný pojem ,vkus“. Oba tyto výrazy nepředstavují v jeho sociologii - jak by se možná mohlo na první pohled zdát - nějaké individuální charakteristiky, ale právě naopak, charakteristiky kolektivní, které vyjadřují vlastnosti určitých sociálních skupiny a tříd.

10 Z tohoto důvodu se $\mathrm{v}$ tomto textu nezabýváme specifickým kontextem náboženství a morálky, do kterého je koncept „homo duplex“ u Durkheima vsazen, ani sekundární literaturou, jež se touto problematikou zabývá. 
vedle jednajícího aktéra i druhá strana, tedy právě onen okolní svět, na jehož určité složky se jednající snaží působit. Tím, že jedinec začíná jednat, dochází k tomu, že potvrzuje relevanci tohoto okolního světa (jedno, zda se k němu vztahuje souhlasně nebo odmítavě). Každý akt jednání, který chce v tomto světě něčeho docílit, je vlastně zároveň stvrzením významu světa. Pokud jedinec jedná - řečeno s Weberem - účelově racionálně, dává na vědomí relevanci účelu, který se v tomto světě rýsuje, i když zatím jenom jako možnost; pokud jedná hodnotově racionálně nebo tradičně, stvrzuje hodnoty a tradice, které jsou v daném společenském prostředí v té či oné míře přijímány, nechává je na sebe působit, a zároveň je tímto způsobem reprodukuje. Společnost takto působí na člověka prostřednictvím jeho vlastního jednání (díky tomu, že jednající uznává peníze, moc, sociální instituce nebo hodnoty, o které v jeho jednání tak říkajíc běží), a zároveň prostřednictvím tohoto jednání působí sama na sebe, na svou reprodukci a změnu.

Člověk poháněn svou individuální vưlí sleduje v jednání své osobní (Durkheim by patrně řekl: egoistické) zájmy a záměry. Zároveň je ale toto jednání společenské, a to ze dvou důvodů: jednak je orientováno směrem $\mathrm{k}$ druhým jedincům, a musí tedy počítat s okolní sociální realitou, jejími pravidly a očekáváními; jednak toto jednání v té či oné míře reprodukuje určité obecné rolové, respektive strukturální vzorce, které, jak říká teorie strukturace, jsou pro jednání zároveň oporou i omezením. Jednající individuum by nemohlo být aktérem, pokud by neprošlo socializačním procesem a neosvojilo si určité společenské požadavky; zároveň ale ve svém jednání musí činit určitá rozhodování a volby, které jsou často závislé nejen na společenské situaci, ale i na jeho ryze individuálních schopnostech, zájmech a preferencích. Obě složky - individuální a společenská - se tedy v lidském jednání vzájemně propojují, podmiňují a podporují. ${ }^{11}$

Pracovně bychom tyto dvě složky jednání mohli rozlišit pomocí pojmů voluntarismus a socialita. Voluntarismus znamená, že v jednání se prosazuje individuální vůle nebo zájem jednající osoby, které jsou její velmi výraznou hnací silou. Socialita znamená, že jednání je prostředkem, jímž společnost utváŕí, reprodukuje a modifikuje sama sebe a udržuje svoji kontinuitu v čase. Obě složky se vzájemně determinují i v tom smyslu, že jedna druhou limitují v rozsahu a míře, v níž se mohou v konkrétním jednání prosadit. ${ }^{12}$ Ve stávajících teoretických koncepcích je voluntarismus často spojován s otázkou motivace a volby, socialita je nahlížena jako problém očekávaného jednání, který je spojen především s konceptem sociální role. Analyticky je možné obě složky odlišit, reálně je to však obtižné, protože obě jsou v rámci jednání mnohonásobně propojeny.

11 Za príklad koncepce, který se blíží tomuto pojetí jednání, lze označit Marxovu ekonomickou analýzu směnných mechanismů, která jsou založena na představě „dvojakého“ charakteru práce práce konkrétní (která je výrazem individuálních schopností výrobce) a práce abstraktní (která je vyjádřením jedincovy účasti na procesu společenské dělby práce a směny).

12 Z historicko-kulturního hlediska je možné předpokládat, že proporce mezi voluntarismem a socialitou mohou být $\mathrm{v}$ jednotlivých typech společností a sociálních skupin rozdílné. Jako př́íklad může posloužit volba životního partnera. V tradičních společnostech jej jednotlivci určují rodiče nebo prríbuzní a mnohdy při tom musí respektovat nejrůznější př́sná společenská pravidla; v moderní společnosti si člověk partnera obvykle vybírá sám, často na základě velmi subjektivních voleb a pocitů. 
Tím, že se jednání lidských jedinců obrací vůči jiným jedincům, vzniká mezi nimi vzájemné působení, tedy interakce. Tyto interakce mohou mít různou podobu a intenzitu, která začíná u efemérních setkání a končí u pevných ustálených vztahů. Specifické zájmy a cíle spojují interagující jedince do určitých interakčních konfigurací, ve kterých lze přes nejrůznější specifické rysy a rozdíly nalézt četné obecně platné principy, jež nám dovolují uvažovat o určitých typických formách, v nichž se toto vzájemné působení odehrává, jako je např́íklad kooperace, konkurence, opozice, konflikt apod.

Většina sociologů zabývající se otázkami interakce rozvíjí koncepce, které se vyznačují jedním společným rysem, jejž lze v daném kontextu považovat za typický. Řečeno s určitou nadsázkou: v teoretickém myšlení těchto autorů se obvykle předpokládá, že jedinci existují jako individua se všemi svými osobitými charakteristikami pouze do okamžiku, než začnou sociálně jednat a interagovat s druhými. V momentu, kdy vstoupí do sociální interakce, se - z pohledu sociologie - jakoby vnitřně proměňují, ztrácí své specifické individuální vlastnosti a přeměňují se na abstraktní, vzájemně zaměnitelné reprezentanty sociálních typů, rolí a institucí, zbavené všech subjektivních rysů. Je evidentní, že i když v zobecňující sociologické perspektivě svět sociálních interakcí svoji barvitost a individuální specifika ztrácí, v realitě si je uchovává. Je to pouze sociologie, která ve vztahu k němu projevuje jakousi metodologickou „slepotu“, jež je způsobena tím, že se snaží od těchto individuálních aspektů odhlédnout jako od něčeho jedinečného a nepodstatného a reflektovat pouze to, co má společensky obecnou platnost. Jinak řečeno, sociologie má tendenci nahlížet v interakční a strukturní perspektivě na lidské jedince jako na zaměnitelné „součástky“ společenského „soustrojí'“.

Zbývá tedy otázka, co může v dané souvislosti nabídnout koncepce, která vychází z perspektivy „duplex“. Interakce teoreticky popisovaná z této perspektivy se jeví jako vzájemný vztah dvou nebo více jedinců, tedy lidských ,já““, z nichž každé má svou individuální a společenskou složku. Jednotlivá jednání těchto jedinců mají opět duální charakter; v každém z nich je možné zaznamenat určitý podíl voluntarismu a zároveň také sociality. Ve zjednodušené modelové podobě to lze vyjádřit tak, že se vưči sobě ve vzájemné interakci vztahují jedinec A a jedinec $\mathrm{B}$, z nich každý představuje pro toho druhého alter ego, o kterém platí, že - podobně jako on sám - má své osobité vlastnosti a dispozice a ve svém jednání sleduje své osobní zájmy a cíle. Zároveň je ale také jako reprezentant určité role či instituce nucen v té či oné míře respektovat i jistá obecná strukturální pravidla, předpisy a vzorce chování. V individuální rovině jde o vzájemnou konfrontaci dvou osobností, v sociální rovině jde o otázku reprodukce rolových vzorců a institucionálních pravidel. Jak individuální, tak i společenské složky osobnosti obou aktérů i jejich jednání mohou v rámci společné interakce představovat faktory facilitující i inhibující povahy, které vůči sobě mohou vystupovat v mnoha různých kombinacích.

\section{Problém struktur v perspektivě duplex}

Problém dosavadních úvah o tomto tématu v sociologickém myšlení - u Giddense i u jiných autorů - spočívá podle našeho soudu především v tom, že struktury jsou ve vztahu k jednání obvykle chápány jako něco jednoúrovňového. Domníváme se, že adekvátnější obraz toho, jak společenské struktury působí, získáme tehdy, jestliže si je dokážeme 
představit jako víceúrovňové, složené z více vrstev, kdy jednotlivé vrstvy struktur do sebe vzájemně zapadají a vzájemně na sebe působí. V opozici vůči zavedené představě se nyní pokusíme ukázat, že i v tomto př́ípadě je možné aplikovat perspektivu, z níž je lze nahlížet jako ,struktury duplex“.

Bude při tom užitečné si na tomto místě připomenout, že Giddens ilustruje vzájemnou spojitost mezi strukturou a jednáním na př́kladu vztahu mezi „langue“ a ,parole“, který přejímá z lingvistiky. „Langue“ v jeho př́kladu zastupuje strukturu, ,parole“ jednání. Giddens ukazuje, že jednání (,„parole“) je možné jedině díky tomu, že existuje struktura (,langue“), která je jeho oporou a zároveň i omezením. Současně tvrdí, že struktura („langue“) může trvat ve své existenci jen díky tomu, že je opětovně reprodukována v jednotlivých opakovaných aktech jednání (,parole“). K tomuto př́íkladu lze poznamenat, že vztah „langue“ a ,parole“ by bylo možné ilustrativně využít i jinak, a sice právě jako př́klad existence dvou strukturálních úrovní. Na první, obecné úrovni, se setkáváme se strukturou jazyka („langue“), na druhé úrovni je možné identifikovat a analyzovat struktury promluv (,parole“).

Pro sociologické myšlení o strukturách je charakteristické, že je v něm zachycena sociální realita jako realita zbavená všech individuálních vlastností a redukovaná pouze na obecné a kolektivní pojmy, vzorce a pravidla. Z hlediska úsilí o dosažení zobecnitelného vědeckého poznání je tato strategie naprosto pochopitelná, přssto ji však nelze uplatňovat v nějaké modelově čisté podobě ve všech humanitně a společensky orientovaných disciplínách. Typickým prŕkladem je historická věda, která se ve svém výkladu nemůže spokojit s tím, aby vykreslovala pouze obecné historické tendence, ale musí umět do svého výkladu zasadit i jednání konkrétních historických osobností, s jejich významem a vlivem. K řešení tohoto problému může podle našeho názoru přispět, pokud se dokážeme i na otázku struktur podívat perspektivou konceptu „duplex“.

V uvedené perspektivě je možné chápat společenské struktury jako dvě úrovně strukturálních pravidel. V první úrovni jsou to obecná pravidla, která vymezují základní sociální instituce a $\mathrm{v}$ jejich rámci stanovují základní rolové pozice a rolová chování. $\mathrm{V}$ druhé úrovni jsou to specifická pravidla, která vznikají v rámci konkrétních lidských skupin, v nichž se objevují určitá očekávání, jež jsou odvozena nebo vynucena na základě individuálních dispozic jejich jednotlivých členů; jsou to pravidla, která jsou v rámci těchto skupin nějakým způsobem sjednána anebo prosazena mocí či silou.

Jako ilustraci navrhovaného prŕstupu lze použít jednoduchý př́klad, v němž budeme uvažovat o nukleární rodině jako představitelce typické sociální instituce a primární sociální skupiny. Uvažujeme-li o rodině jako o instituci, všímáme si obecných pravidel, která definují obsah základních rolí (matka, otec, dítě), případně - akceptujeme-li funkcionalistický přístup - stanovují obsah základních funkcí (reprodukční, ochranná, emocionální, ekonomická, výchovná), jež tato strukturální jednotka plní. Pokud se však zaměříme na konkrétní rodinu, kterou nahlížíme jako malou sociální skupinu, pak se naše pozornost může obrátit ještě k další úrovni pravidel, která už mají specifický charakter a jež byla sjednána nebo prosazena $\mathrm{v}$ důsledku konkrétních vlastností, předpokladů a možností jednotlivých členů rodiny (např́íklad pravidla, kdo vyzvedává dítě ze školky, kdo seká trávník či kdo venčí psa). Na uvedeném př́kladu si můžeme povšimnout, že institucionální pravidla jsou jakoby diktována společností, zatímco pravidla fungování konkrétní lidské skupiny vycházejí v té či oné míře 
z individuálních vlastností jejích členů. V praxi se oba typy pravidel spolu navzájem propojují, vzájemně se doplňují a je obtížné je od sebe striktně oddělit.

Podobných př́ikladů, které ukazují víceúrovňový charakter společenských struktur, bychom mohli uvést velké množství. Dobře lze tuto skutečnost ilustrovat třeba na př́íkladu sportovního utkání, které probíhá podle př́slušných pravidel dané sportovní disciplíny, ale samo toto utkání je pak ještě dále strukturováno strategiemi a schopnostmi, které v jeho průběhu uplatňují jednotlivé týmy a jejich hráči. Obdobným způsobem můžeme uvažovat o fungování různých typů sociálních skupin, organizací i společenských systémů (v oblasti politiky se např́klad systémy, které obecně můžeme označit jako demokratické, nebot' v nich jsou uplatňována demokratická pravidla vládnutí, mohou odlišovat v konkrétní formě svého projevu, a to jak v důsledku odlišných procedurálních pravidel, tak i podle toho, jakým konkrétním způsobem uplatňují svoji moc reprezentanti vedoucích politických stran).

V žádném př́ípadě nechceme popírat, že sociální systémy jsou schopny seberegulace. Nejpřesvědčivěji tuto schopnost dokládá ekonomický systém disponující seberegulačním mechanismem, který již kdysi dávno Adam Smith označil výrazem „neviditelná ruka trhu“. Avšak právě krizový vývoj tohoto systému v poslední době zřetelně ukazuje, že to, co se v něm reálně odehrává, není jenom důsledkem působení nějakých živelných nadindividuálních sil a systémových mechanismů, ale je také výsledkem působení mnoha lidských aktérů, zejména těch, kteří v roli špičkových manažerů peněžních ústavů činili fatálně chybná ekonomická rozhodnutí, jež, jak se ukázalo, měla masový dopad.

Pro dosavadní teoretické úvahy je většinou charakteristické, že vliv na formování sociální reality je aktérům přiznáván pouze na mikrosociální úrovni (kde je také hojně zkoumán, zejména prŕstupy sociálního konstruktivismu). Výrazně opomíjenou otázkou však zůstává, zda a jakým způsobem mohou aktéři projevovat svůj vliv také na makrosociální úrovni. Na tento fakt upozorňuje Nicos Mouzelis, který konstatuje, že daný problém nelze úspěšně řešit, pokud nevezmeme dostatečně na zřetel to, jak je moderní společnost hierarchicky organizována a jakou roli v rámci této hierarchie sehrávají tzv. „makro-aktéŕi“ (Mouzelis 2006: 20). K tomu si dovolme poznamenat, že právě idea „struktur duplex“ otevírá podle našeho soudu možnost, jak k tomuto teoretickému rébusu přistoupit.

Jednou z otázek, na které soudobá sociologická teorie nemá odpověd’, a vlastně ani necítí potřebu tuto odpověd’ hledat, je, jakým způsobem mohou jedinci ovlivňovat makroúroveň celospolečenských struktur a procesů. I když je problému aktérů jako tvưrců sociální reality - a to zejména díky sociálnímu konstruktivismu - v soudobé sociologii prrisuzováno důležité místo, je obvyklé, že se pozornost sociologie zaměřuje pouze na drobné anonymní aktéry a jejich aktivity běžného každodenního života, sledované na mikrosociální úrovni. Zdá se, že pokud se má sociologie zabývat jevy na makrosociální úrovni, není v zásadě schopna uvažovat jinak než funkcionalisticky. To je paradoxně i př́pad Giddense, který sice funkcionalismus verbálně odmítá, avšak ve svých pracích věnovaných aktuálním jevům pozdní moderny do něj nereflektovaně na řadě míst upadá.

Otázka jedinců s celospolečenským vlivem je celkem běžná a legitimní v rámci historických věd, sociologie ji naopak - dalo by se říci „ze zásady“ - ignoruje. S určitým zjednodušením můžeme konstatovat, že po dlouhá léta jsme svědky toho, že zatímco historie má tendenci vidět společenské procesy jako dílo významných historických osobností, 
sociologie má naopak tendenci tyto procesy nahlížet jako projev nadindividuálních společenských celků, struktur a sil či sociálních systémů a jejich funkcí. Odhlédneme-li od soudobých směrů historického bádání orientovaných na sociální dějiny či dějiny každodennosti, můžeme konstatovat, že pro tradičně pojímanou historii je minulost především zřetězením činů významných jedinců. Naopak sociologie, a platí to i o soudobé historické sociologii, vidí v minulosti především procesy sociálních změn, které probíhají na úrovni kultury, civilizace a jednotlivých typů forem lidského soužití či společenských formací. Ještě jinak řečeno, v historické vědě se výrazně prosazuje individualistický prŕístup, v historické sociologii naopak prŕstup holistický.

Nechme stranou otázku metodologie historických věd (tu si musí klást a řešit sami historikové) a podívejme se na problém výkladu, který je schopna nabídnout sociologie, prrípadně historická sociologie. Je zřejmé, že řadu témat, zvláště jedná-li se o obecné trendy ve vývoji kultury, civilizace či moderny, je možné sledovat adekvátním zpo̊sobem z holistické perspektivy a lze prri tom odhlížet od úlohy, kterou sehrávaly významné historické osobnosti. Jsou však i jiné výzkumné otázky, kde se vliv těchto osobností úplně ignorovat nedá. V případě české sociologie je to např́klad analýza období vlády komunismu, převratu v roce 1989 a transformačního vývoje, který po něm následoval. Vysvětlovat tuto etapu ve vývoji společnosti jen jako pohyb anonymních mas či dynamiku obecných principů a tendencí a odhlížet od těch, kdo byli vůdci a „architekty“ společenských přeměn, by bylo nedostatečné. Individuální prvek sehrává ve společnosti vždy určitou úlohu, díky němu má společenský vývoj a charakter společenského soužití své specifické rysy. I jeho zásluhou se v sociální realitě objevují nové, nečekané jevy, v jejichž důsledku je tak obtížné společenský vývoj prognózovat. Sociologii však stále chybí pro uchopení problematiky těchto „makro-aktérư“ adekvátní teoreticko-metodologické instrumentarium.

Konceptuální aparát, kterým sociologie v tomto př́padě disponuje, má svůj původ u zakladatelů sociologického myšlení. Připomeňme, že Max Weber vypracoval koncepci ideálních typů panství (charismatického, tradičního a legálního), Vilfredo Pareto formuloval teorii elit, Robert Michels zaměřil pozornost na stranické vůdce. V̌̌echny tyto starší ale také novější přístupy se obvykle zaměřují na to, aby jedince na vrcholech společenských hierarchií identifikovaly jako určitý společenský typ nebo skupinu a aby zároveň postihly ty jejich sociální charakteristiky, které lze ze sociologického hlediska pokládat za podstatné, určující a zároveň i diferencující. To, co v nich však absentuje, je vysvětlení mechanismů, které umožňují, že se jednání těchto jedinců může promítat do utváření společenských makrostruktur.

Budiž řečeno, že podle našeho názoru je to právě idea ,struktur duplex“, která by mohla k objasnění tohoto problému určitým zpưsobem přispět. Vysvětlení, které nabízí, spočívá $\mathrm{v}$ hypotéze, že se v tomto prrípadě jedná o takové jedince, kteří díky své společenské pozici (elitnímu či monopolnímu postavení) mají možnost ovlivňovat sociální makrostruktury tím způsobem, že jsou schopni doplnit úroveň obecných makrostrukturálních pravidel o další specifickou vrstvu pravidel, která je odrazem jejich osobitých rysů, specifik jednání, vizí, představ, prání, objevů, ale také třeba i omezenosti, patologických sklonů, zvrácených nápadů či úchylek. Ty jsou pak díky moci a vlivu, kterým disponují, uplatňovány v celospolečenském měřítku. Nastíněným způsobem lze přistoupit $\mathrm{k}$ objasnění - řečeno s Plechanovem „úlohy osobnosti v dějinách“ jak v pozitivních, tak i negativních př́ípadech; uvedeným 
způsobem si lze přiblížit podstatu vlivu vynikajících historických osobností, ale také třeba tyranů a diktátorů.

\section{Závěrem}

V této stati jsme se pokusili ukázat, že řešení tradičního teoretického dilematu, který představuje opozice individualistického a holistického prŕstupu, nabízí koncepce, která je do určité míry inspirována Durkheimovým pojetím „homo duplex“. Durkheim pojímá lidskou přirozenost jako vnitřně rozpornou, jako protikladnou jednotu egoismu a společenskosti. V návaznosti na to se pokoušíme ukázat, že takto vnitřně protikladné jsou všechny základní koncepty, s nimiž se ve strukturační teorii pracuje, tzn. nejen koncept aktéra, ale také koncept jednání, interakce a struktur. V každém z nich, jak bylo ukázáno, můžeme identifikovat složku, která má individuální povahu, a složku, která má společenskou povahu. Váhy těchto složek jsou pochopitelně v jednotlivých konkrétních případech rozloženy různým způsobem.

V př́ípadě aktéra zvýrazňuje perspektiva „duplex“ dvojakost lidského ,já“, tedy subjektivitu individuálního ega i objektivní dimenzi socializované bytosti. V návaznosti na to je pak možné vidět individuální jednání jako rozpornou jednotu voluntarismu a sociality. Interakce vznikající v důsledku sociálního jednání představují vzájemné působení lidských bytostí, do kterého jedinci vstupují se svými individuálními záměry a cíli, avšak zároveň se jeho prostřednictvím podílejí na reprodukci obecných rolových vzorců a institucí. Konkrétní sociální skupiny a organizace jsou tvořeny a reprodukovány jednáním konkrétních individuí a nesou tak charakteristické rysy jejich individuálních dispozic a výkonů; současně však toto jednání vede k reprodukci a udržování obecných institucionálních pravidel. Struktury tímto způsobem fungují jako víceúrovňové vrstvy pravidel, z nichž některé jsou utvářeny autopoietickými systémovými procesy, zatímco jiné jsou více či méně záměrným produktem činnosti konkrétních aktérů. Jak je zřejmé, jedinec a společnost nejsou v této perspektivě skutečnými protiklady. $\mathrm{V}$ každém individuu je př́tomna společnost a $\mathrm{v}$ každé společnosti jsou př́tomni jedinci. Jak jednání, tak i struktury mají subjektivní i objektivní charakter.

Domníváme se, že v podstatě celá sociální realita, jež je předmětem sociologického zkoumání, by měla být takto nahlížena $\mathrm{v}$ jednotě obou hledisek současně. Teorie, jejíž náčrt jsme se pokusili představit, by měla být budována tak, aby byla schopna reflektovat, že na jednotlivé jevy sociálního života lze vždy nahlížet z obou pohledů, tj. z pohledu individuálního i společenského. Tato dvě hlediska jsou nejen komplementární, ale vnitřně vzájemně podmíněná, a výklad, který je veden pouze z pozice jednoho z nich, je vždy nutně jednostranný a neúplný. Proto navrhujeme takový př́stup $\mathrm{k}$ formulování teoretických konceptů, který bude tuto dvojakost odrážet a bude ukazovat, že ke každému zkoumanému problému je možné prristupovat $\mathrm{z}$ obou perspektiv naráz. Jestliže přijmeme tento předpoklad, pak už proti individuálnímu (jedinečnému) jednání nestojí nadindividuální (obecné) společenské struktury a systémy, nýbrž všechny tyto koncepty jsou koncipovány tak, že každý z nich má vždy svou individuální a svou nadindividuální (obecnou, kolektivní) složku a ta je ve vzájemné korespondenci s ostatními kategoriemi, jež jsou vymezeny obdobným způsobem. Přednost tohoto přistupu spočívá podle našeho názoru v tom, že se jím dá vcelku uspokojivě vyřešit tradiční 
rozpor mezi jednotlivcem a společností, který Giddens transponoval do podoby duality jednání a struktury. Podíváme-li se na problém prizmatem konceptu „duplex“, pak už proti individuální vưli jedince nestojí nadosobní struktura společnosti, ale stojí tu proti sobě ve vzájemné korespondenci dvě entity, z nichž každá má svou individuální a svou společenskou složku, i když samozřejmě každá v jiné míře a rozsahu.

Přístup, o kterém hovoříme, je zatím spíše jen sada teoretických hypotéz. Nemyslíme si, že by bylo možné od takového přístupu očekávat vyřešení všech problémů spojených s otázkou duality jednání a struktury, na druhou stranu se ale domníváme, že se jedná o perspektivu, kterou má cenu dále rozvíjet. Nicméně, i kdyby se v budoucnu podařilo vyřššit problém dualismu jednání a struktury přesvědčivějším způsobem, než jaký nabízí Giddensova teorie strukturace, přesto by to patrně nevedlo k opuštění individualistických ani holistických pozic. Důvodem je jednoduše skutečnost, že sociální realita je polykontextuální a jednotlivé konkrétní události, které se v ní odehrávají, je možné nahlížet z různých perspektiv: z individualistické perspektivy, z holistické perspektivy i z perspektivy, která se snaží individualismus a holismus vzájemně propojit a překonat. V konkrétním př́padě pak bude vždy nepochybně záležet především na tom, který výklad se při zkoumání určitého sociálního jevu ukáže jako nejproduktivnější a nejpřesvědčivější.

\section{Literatura}

ARCHER, Margaret S. Morphogenesis vs. Structuration. British Journal of Sociology, 1982, roč. 33, č. 4, s. 455-483. ISSN 1468-4446.

ARCHER, Margaret S. Realist Social Theory: The Morphogenetic Approach. Cambridge: Cambridge University Press, 1995. 368 s. ISBN 978-0521484428.

ARCHER, Margaret S. „Lze najít pojítko mezi vysvětlením a porozuměním?“ Sociologický časopis, 2008, roč. 44, č. 1, s. 7-22. ISSN 0038-0288.

BHASKAR, Roy. „On the Possibility of Social Scientific Knowledge and the Limits of Naturalism.“ Journal for the Theory of Social Behavior, 1978, roč. 8, č. 1, s. 1-28. ISSN 1468-5914.

COLEMAN, James S. Social Theory, Social Research, and a Theory of Action. American Journal of Sociology, 1986, roč. 91, č. 6, s. 1309-1335. ISSN 0002-9602.

COLEMAN, James S. Foundations of Social Theory. Cambridge (MA): The Belknap Press of Harvard University Press, 1994. 993 s. ISBN 0-674-31226-0.

COLLINS, Randall. „On the Microfoundations of Macrosociology.“ American Journal of Sociology, 1981, roč. 86, č. 5, s. 984-1014. ISSN 0002-9602.

COLLINS, Randall. Theoretical Sociology. San Diego: Harcourt Brace Jovanovich, 1988. 565 s. ISBN 015591474X.

DURKHEIM, Émile. „Le probléme religieux et la dualité de la nature humaine.“ Bulletin de la Société Francaise de la Philosophie, 1913. Vol. XIII., s. 63-113.

DURKHEIM, Émile. „La dualisme de la nature humaine et ses conditions sociales.“ Scientia, 1914. Vol. XV., s. 206-222.

DURKHEIM, Émile. „Dualismus lidské přirozenosti a její společenské podmínky.“ In: Antropologie, sociologie, historie. Cahiers du CEFRES, 1995, č. 8, s. 16-34. ISBN 978-80-86311-26-5, ISSN 1805-0336.

FAY, Brian. Současná filosofie sociálních věd: Multikulturni přistup. Praha: Sociologické nakladatelství, 2002. 324 s. ISBN 80-86429-10-5. 
GIDDENS, Anthony. New Rules of Sociological Method. London: Hutchinson, 1976. 192 s. ISBN 0-8047-1944-6.

GIDDENS, Anthony. Central Problems in Social Theory: Action, structure and contradiction in social analysis. Berkeley: University of California Press, 1979. 294 s. ISBN 0520039750.

GIDDENS, Anthony. „Time and Space in Social Theory“. In MATTHES, J. (ed.) Lebenswelt und soziale Probleme. Frankfurt/M.: Campus Verlag, 1981. s. 88-97. ISBN 9783593326955.

GIDDENS, Anthony. The Constitution of Society: Outline of the Theory of Structuration. Berkeley: University of California Press, 1984. 402 s. ISBN 0520052927.

GIDDENS, Anthony. Die Konstitution der Gesellschaft. Grundzüge einer Theorie der Strukturierung. Frankfurt/M: Campus Verlag, 1988. 460 s. ISBN 3-593-34744-X.

HABERMAS, Jürgen. Theorie des kommunikativen Handelns, Band 1,2. Frankfurt/M.: Suhrkamp, 1981. 1166 s. ISBN 3-518-28775-3.

JOHNSON, Doyle Paul. Contemporary Sociological Theory: An Integrated Multi-Level Approach. New York: Springer, 2008. 629 s. ISBN 0387765212.

KELLER, Jan. Dẽjiny klasické sociologie. Praha: Sociologické nakladatelství, 2004. 529 s. ISBN 80-86429-34-2.

KING, Anthony. „Struktura a jednání.“ In HARRINGTON, A. a kol., Moderní sociální teorie: Základni témata a myšlenkové proudy. Praha: Portál, 2006. s. 291-312. ISBN 8073670933.

LAYDER, Derek. Understanding Social Theory. London: SAGE, 1994. 230 s. ISBN 9780803984493.

MAHLMANN, Regina. Homo Duplex: Die Zweiheit des Menschen bei Georg Simmel. Würzburg: Könighausen + Neumann, 1983. 224 s. ISBN 3884791273.

MEAD, George H. On Social Psychology. Chicago: The University of Chicago Press, 1977. 358 s. ISBN 0226516652.

MÜLLER, Hans-Peter. Sozialstruktur und Lebensstile: Der neuere theoretische Diskurs über soziale Ungleichheit. Frankfurt/M.: Suhrkamp, 1992. 263 s. ISBN 3-518-29296-X.

SIMMEL, Georg. Brücke und Tür: Essay der Philosophen zur Geschichte, Religion, Kunst und Gesellschaft. Stuttgart: K.F. Koehler, 1957. 281 s.

\section{Autor}

Jiř́ Šubrt je vedoucím a jedním ze zakladatelů pracoviště Historické sociologie na FHS UK v Praze. Vyučuje také na katedře sociologie FF UK. Věnuje se sociologické teorii, problematice času, historickému vědomí a kolektivní paměti.

Kontakt: jiri.subrt@ff.cuni.cz 